mexicano. Ella debe "crear" la filosofía mexicana del pasado: "no hay filosofía mexicana en la medida en que no hay Historia de la Filosofía Mexicana" (I, pág. 86).

El segundo tomo se dedica al estudio de la filosofía del mexicano o -como otros prefieren decir- de lo mexicano. Se presenta en forma de una serie de aporias con las que tiene forzosamente que enfrentarse esa dirección filosófica. En última instancia, todas ellas podrían reducirse a la oposición aparente entre la esencia del mexicano que se pretende explicitar y la existencia histórica del ejemplar que se toma por estudio.

La primera aporia está implicada en toda fenomenología eidética. Para definir la esencia tenemos que dirigirnos a un ejemplar concreto; pero la elección de ese ejemplar implica, a su vez, el previo conocimiento de la esencia. Aparente círculo vicioso. Esta dificultad -de raigambre nominalista- se dobla con la dificultad de determinar con precisión las notas del ejemplar que pertenecen a la esencia y aquellas que no le pertenecen. No podríamos, en nuestro caso, tomar como criterio la Fundierung, de Husserl, pues ésta sólo sería aplicable a las esencias morfológicas de géneros y especies y no a substancias tales como "el mexicano". Estas dos aporías se basarían en una dificultad más radical: la imposibilidad de que hubiera esencias de entes puramente históricos. "No habria esencias de las cosas puramente históricas. Por eso éstas no serian definibles, sino historiables - tan sólo: el ideal de la definición forzosamente abandonado" (II, p. 28). ¿Habría, pues, que abandonar todo intento de descripción fenomenológica del mexicano? De ningún modo. Asi como la descripción de esencias se topa con un límite en la existencia histórica irreductible, asi también el "historiar" al mexicano se topa necesariamente con un limite esencial. "La Historia no puede escribirse sin una buena dosis de tér- minos expresivos de esencias" (II, pág. 29). La unidad de la historia implica una definición esencial de su objeto. Tanto el historicismo como el existencialismo radicales tropiezan con limites esencialistas. Pensar la existencia o la historia implica advenir a un logos eidético que la exprese. Esencialismo y existencialismo absolutos son imposibles. Ambos serían, más bien, términos que reciprocamente se implican. De ahí que historiar al mexicano y describirlo fenomenológicamente puedan implicarse mutuamente. Historia y fenomeno. logía "cooperan a la confección existencial e histórica de las esencias" que, a su vez, "son objeto de una confección semejante ellas mismas" (II, pág. 48).

Gaos termina su estudio señalando algunos de los peligros que amenazan a la filosofía del mexicano; un "este. ticismo" reñido con la práctica, un nacionalismo mal entendido, una derivación interesada hacia actitudes politicas, podrian ser escollos que la malograran.

\section{LUIS VILLONo}

\section{Filosofia mexicana de nuestros dias, por José Gaos. Colección Cultura Mexicana, Imprenta Universita- ria, México, 1954.}

Este nuevo libro de José Gaos defraudaría al lector que se dejase ilusionar por la promesa del titulo, si el autor mismo, hasta cierto punto, no se encargara en el Prólogo de prevenir o detener esa ilusión. Se indica en ese Prólogo que la obra reproduce una serie de críticas de libros y artículos informativos publicados en México por el autor "durante los últimos ocho años". Pero el autor no ha incluido en la serie todos los trabajos publicados por él mismo sobre filosofía mexicana contemporánea; $y$, por otra parte, ni en los inclusos, ni en los excluidos, se trata de algunas corrientes y de algunas figuras de esa filosofía. Ámbas cosas las re- 
conoce el autor, y es evidente que sólo dependía de su arbitrio el criterio con que habia de seleccionar sus propios trabajos. Pero, sin coartar para nada su libertad, es cierto también que la adopción del criterio le planteaba una alternativa: o incluir todos los trabajos publicados ya por él, sin las exclusiones justificadas (ni otras que no justifica), y acaso completarlos con otros que ayudaran a cumplir lo que el título promete; o bien cambiar el título, reduciendo la ambición de su alcance a las dimensiones de lo que el texto ofrece de hecho.

Desde luego, hubiera sido preferible para la mejor información de todo el mundo, y más equitativo, mantener el título de la obra y acomodar el contenido de ésta a lo que el título mismo denota. Y este parecer podría apoyarse con varios ejemplos de omisiones no justificadas por el autor; para citar sólo uno, es singular que no haya en la obra de Gaos mención alguna del libro de Samuel Ramos Filosofia de la vida artística (Espasa-Calpe, Argentina, 1950), el cual, aparte de sus méritos intrínsecos, es una de las poquísimas obras sistemáticas de estética que se hayan producido en México.

Pero una selección de trabajos propios es lo mismo que una antologia de trabajos ajenos: lo que más patente se hace en ella, por afinidad, es la personalidad del seleccionador, o aquel aspecto de ella que se manifiesta en sus propensiones y predilecciones. Contrasta, en efecto, con las omisiones, justificadas o no, el amplio espacio de más de sesenta páginas dedicado a la llamada "filosofía del mexicano" y sus cultivadores. Sería conveniente desvanecer el equívoco de esta expresión, "filosofía del mexicano", por la cual puede entenderse la sociología, la psicología, la ética sobre todo, que versen sobre modos de ser del mexicano; y puede entenderse también la filosofía que haga el mexicano al ocuparse de los mismos problemas de que se ocupa la filosofia en todas partes. Y si esta última filosofia ha llegado a ser realmente valiosa, entonces la madurez espiritual y la capacidad de creación que revele su pensamiento universal acaso logren convencernos de que lo decisivo, filo. sófica y mexicanamente hablando, es ser filósofo uno mismo, activa y auténticamente.

En suma, el lector extranjero en cu. yas manos se encuentre un libro titulado así : Filosofia mexicana de nuestros días, y escrito por un profesor de tal relieve, está autorizado a preguntarse antes de abrirlo: ¿Qué novedades importantes han traido los filósofos mexicanos contemporáneos? ¿Qué ideas originales se han producido, con mayor o menor fuerza de persistencia, sobre metafísica, sobre teoría del conocimiento, sobre estética y antropología, sobre filosofía de la historia? El libro de Gaos no responde adecuadamente a esas preguntas.

El profesor Gaos está excepcionalmen. te dotado, por sus capacidades personales y por su preparación, para escribir estudios de filosofía con el dominio técnico, el rigor metódico y la agudeza analítica que exhibe en sus cursos y seminarios. Para ello no se requieren capacidades literarias excepcionales. Pero es un hecho que la mayoria de los tra. bajos de Gaos se orienta precisamente hacia el sector más "literario" de la fi. Iosofía; y no deja de ser desconcertante la decisión que ha tomado, y que ha mantenido durante años, de descuidar en sus escritos aquella parte de su trabajo que es más valiosa filosóficamente y en la cual se manifestarian mejor sus cualidades intelectuales.

N.

La conciencia del hombre en la filosofia. Introducción a la filosofía, por Leopoldo Zea. Imprenta Universitaria, México, 1953.

Este libro de Leopoldo Zea, anterior a todos los ya publicados por él, salvo, 